\title{
PENGETAHUAN IBU, DUKUNGAN KELUARGA DAN PETUGAS KESEHATAN DENGAN PEMBERIAN ASI EKSKLUSIF
}

\author{
Ketut Catur Anggrawati ${ }^{1 凶}$, Anna V. Pont ${ }^{1}$, Rafika ${ }^{1}$, Masudin ${ }^{2}$ \\ ${ }^{1}$ Jurusan Kebidanan Poltekkes Kemenkes Palu \\ ${ }^{2}$ Jurusan Keperawatan Poltekkes Kemenkes Palu
}

\author{
ARTICLE INFO \\ Article History \\ Submitted : 2018-08-08 \\ Revised : 2019-07-10 \\ Accepted : 2019-07-22

\section{Keywords:} \\ Exclusive Breastfeeding \\ Knowledge \\ Family Support \\ Health Officer Support
}

\begin{abstract}
Breast Milk contains antibody-rich colostrum because it contains high immune proteins and germ killers so exclusive breastfeeding can reduce infant mortality. Exclusive breastfeeding achievement in Mamboro Community Center in 2015 was 118 "71.95\%" and 2016 decreased by 183 "62\%". Factors that cause the baby not to get exclusive breastfeeding include education, knowledge, values or cultural customs, family support and support of health workers. The purpose of this research is to know the relationship of mother's knowledge, family support and support of health officer with exclusive breast feeding in Posyandu working area of Mamboro Community Health Center. This research use analytic survey method withapproach cross sectional, data collecting using primary data is by filling questionnaires on mothers who have infants aged 6-12 months, research conducted on 14 April to 16 May 2018. Sampling technique is purposive sampling with inclusion and exclusion criteria with a total sample of 55 respondents. Analysis of bivariate data usingstatistical test Chi Square with 95\% confidence level $(\alpha=0,05)$. The result of statistic test showed that the relationship of mother's knowledge with exclusive breastfeeding was obtained $p$ value of 0,04 ( $p$ value <0,05), relation between family support and exclusive breastfeeding was obtained $p$ value 0,333 ( $p$ value $>0,05$ ) and the relationship between health care support and exclusive breastfeeding was obtained by $p$ value of 0.40 ( $p$ value $>0.05$ ). In conclusion there is a relationship between mother knowledge with exclusive breastfeeding in Posyandu work area of Mamboro Community Health Center. Trying to educate and increase knowledge Mother'sabout exclusive breastfeeding, do counseling during exclusive breastfeeding period and always involve husband in giving related information about ASI.
\end{abstract}

Corresponding Author:

Ketut Catur Anggrawati

Jurusan Kebidanan Poltekkes Kemenkes Palu

Telp. 085250192463

Email: caturanggrawati@gmail.com

\section{PENDAHULUAN}

Menyusui akan menjamin bayi tetap sehat dan memulai kehidupannya dengan cara yang paling sehat. World Health Organisation (WHO) telah mengkaji atas lebih dari 3.000 menunjukan pemberian ASI selama 6 bulan adalah jangka waktu yang paling optimal untuk pemberian ASI eksklusif. Hal ini berdasarkan pada bukti ilmiah bahwa ASI eksklusif mencukupi kebutuhan gizi bayi dan pertumbuhan bayi lebih baik. Negara Indonesia setiap tahunnya lebih dari 25.000 bayi dan 1,3 juta bayi diseluruh dunia dapat diselamatkan dengan pemberian ASI eksklusif (Haryono dan Setianingsih, 2014).

Air Susu Ibu (ASI) mengandung kolostrum yang kaya akan antibodi karena mengandung protein untuk daya tahan tubuh dan pembunuh kuman dalam jumlah tinggi sehingga pemberian ASI eksklusif dapat mengurangi resiko kematian pada bayi (Kemenkes, 2015).

Pencapaian ASI eksklusif di Indonesia pada tahun 2015 sebesar 55,7\% (Kemenkes, 2015). Berdasarkan Data dan Informasi Profil Kesehatan Indonesia 2016 persentase bayi baru lahir yang mendapatkan ASI eksklusif di 
Indonesia sampai 6 bulan sebanyak 29,5\% dan ASI eksklusif 0-5 bulan sebesar 54,0\%. Jumlah bayi yang diberi ASI eksklusif di Provinsi Sulawesi Tengah Tahun 2015 sebanyak 20.455 (56,0\%). Pada tahun 2016 jumlah bayi yang diberi ASI eksklusif sebanyak 19.345 (56,3\%) yaitu mengalami peningkatan $0,3 \%$ (Dinas Kesehatan Provinsi Sulawesi Tengah, 2015 dan 2016).

Cakupan ASI eksklusif di Kota Palu tahun 2015 sebesar 67,6\%, tahun 2016 sebesar $64,4 \%$ yaitu mengalami penurunan sebesar $4 \%$ (Dinas Kesehatan Kota Palu, 2015 dan 2016). Cakupan ASI eksklusif di Puskesmas Mamboro tahun 2015 sebesar 71,95\%, tahun 2016 sebesar $62 \%$ mengalami penurunan sekitar $10 \%$ (Puskesmas Mamboro, 2015 dan 2016).

Terdapat lima faktor yang menyebabkan bayi tidak mendapatkan ASI eksklusif antara lain pendidikan, pengetahuan, nilai-nilai atau adat budaya, dukungan keluarga dan dukungan petugas kesehatan (Haryono dan Setianingsih, 2014:26). Menurut Baskoro (2008) dalam Wowor dkk (2013) kendala ibu dalam menyusui ada dua faktor yaitu faktor internal kurangnya pengetahuan ibu tentang manajemen laktasi dan faktor eksternal yaitu ASI belum keluar pada hari-hari pertama sehingga ibu berpikir perlu tambah susu formula, ketidakmengertian ibu tentang kolostrum dan ibu masih beranggapan bahwa ASI ibu kurang gizi kualitas tidak baik.

Masalah pemberian ASI terkait dengan masih rendahnya pemahaman ibu, keluarga dan masyarakat tentang ASI. Tidak sedikit ibu yang membuang kolostrum karena dianggap kotor sehingga perlu dibuang. Selain itu, kebiasaan memberikan makanan dan atau minuman secara dini pada sebagian masyarakat juga menjadi pemicu dari kurangnya keberhasilan pemberian ASI eksklusif (Maryunani, 2015).

Kontinuitas menyusu dapat dipengaruhi oleh dukungan sosial dari orang lain yang berinteraksi dengan ibu sehingga ibu tersebut dapat merasakan kenyamanan secara fisik dan psikologis. Orang lain ini terdiri atas pasangan hidup, orang tua, saudara, teman, tenaga kesehatan dan anggota kelompok kemasyarakatan (Astutik, 2017). Sikap keluarga di rumah terhadap pemberian ASI juga berpengaruh. Seperti pada saat di rumah apabila ibu mendapatkan dukungan untuk memberikan ASI, maka ibu tetap bertahan menyusui. Sebaliknya, bila keluarga di rumah kurang mendukung pemberian ASI maka ibu tidak akan meneruskan menyusui. Sikap suami, orang tua, kerabat, tetangga, terhadap pemberian ASI dapat berpengaruh terhadap keputusan ibu untuk menyusui atau tidak (Handayani dan Pujiastuti, 2016).

Berdasarkan hasil penelitian oleh Sipahutar, dkk (2017) menyatakan ada hubungan pengetahuan, parietas dan peran petugas kesehatan dengan pemberian ASI eksklusif. Penelitian yang dilakukan oleh Lestari dkk (2013) menyatakan terdapat hubungan yang bermakna antara tingkat pengetahuan ibu dan pekerjaan tentang ASI dengan pemberian ASI eksklusif. Berdasarkan penelitian yang dilakukan oleh Susmaneli (2012), hasil penelitiannya menyatakan informasi dari tenaga kesehatan, dukungan keluarga dan pengetahuan berhubungan dengan pemberian ASI eksklusif.

Tujuan penelitian ini adalah untuk mengetahui hubungan pengetahuan ibu, dukungan keluarga dan dukungan petugas kesehatan dengan pemberian ASI eksklusif di Posyandu wilayah kerja Puskesmas Mamboro.

\section{METODE PENELITIAN \\ Jenis Penelitian}

Jenis penelitian yang digunakan dalam penelitian ini adalah survei analitik dengan pendekatan cross sectional.

\section{Waktu dan Tempat Penelitian}

Penelitian dilakukan di Posyandu wilayah kerja Puskesmas Mamboro pada tanggal 14 April sampai dengan 16 Mei 2018.

\section{Populasi dan Sampel}

Populasi dalam penelitian ini adalah semua ibu yang mempunyai bayi usia $6-12$ bulan yang melakukan kunjungan di Posyandu wilayah kerja Puskesmas Mamboro. Terdiri atas 13 Posyandu yang terdapat di tiga desa/kelurahan, yaitu Kelurahan Taipa, Kelurahan Mamboro dan Kelurahan Mamboro Barat yaitu sebanyak 116.

Perhitungan besar sampel menggunakan rumus Slovin, diperoleh jumlah sampel sebanyak 55 responden, tehnik pengambilan sampel yaitu dengan purposive sampling dengan kriteria inklusi yaitu ibu yang mempunyai bayi usia $6-12$ bulan, melakukan kunjungan di Posyandu wilayah kerja Puskesmas Mamboro, dapat berkomunikasi dan 
kriteria eksklusi yaitu ibu yang bersalin di dukun, memiliki kontraindikasi menyusui dan tidak bersedia menjadi subjek penelitian.

\section{Pengumpulan Data}

Dalam penelitian ini pengumpulan data dilakukan dengan pengisian kuesioner.

\section{Pengolahan dan Analisa Data}

Pengolahan data pengetahuan ibu, dukungan keluarga, dukungan petugas kesehatan dan ASI ekslusif diolah melalui proses editing, coding, entry, cleaning dan tabulation. Analisis data bivariat menggunakan uji Chi Square.

\section{HASIL PENELITIAN}

Tabel 1. menunjukan bahwa mayoritas responden adalah berusia $20-35$ tahun, berdasarkan tingkat pendidikan ternyata lebih banyak yang berpendidikan tinggi $(69,1 \%)$, namun tingginya pendidikan tidak sesuai dengan pekerjaan responden, yaitu lebih banyak yang tidak bekerja dibandingkan bekerja. Inisiasi Menyusu Dini (IMD) sudah cukup baik, yaitu sebesar 54,5\% pernah melakukan IMD.

Tabel 1. Karakteristik Responden Ibu yang Memiliki Bayi 6 - 12 Bulan di Posyandu Wilayah Kerja Puskesmas Mamboro

\begin{tabular}{lcc}
\hline \multicolumn{1}{c}{ Variabel } & Frekuensi (n) & Persentase (\%) \\
\hline Umur Ibu & & \\
$\quad<20$ dan $>35$ tahun & 10 & 18,2 \\
$20-35$ tahun & 45 & 81,8 \\
Pendidikan & & \\
$\quad$ Tinggi & 38 & 69,1 \\
$\quad$ Rendah & 17 & 30,9 \\
Pekerjaan & & \\
$\quad$ Tidak bekerja & 44 & 80,0 \\
$\quad$ Bekerja & 11 & 20,0 \\
IMD & & \\
Ya & 30 & 54,5 \\
Tidak & 25 & 45,5 \\
\hline
\end{tabular}

Berdasarkan tabel 2. menunjukan bahwa bayi yang tidak mendapatkan ASI eksklusif yaitu sebayak $52,7 \%$, memiliki pengetahuan baik sebanyak $52,7 \%$, mendapat dukungan keluarga sebanyak 52,7\% dan yang mendapat dukungan petugas kesehatan sebanyak $65,5 \%$.

Tabel 2. Distribusi Frekuensi Responden menurut Pemberian ASI Eksklusif, Pengetahuan, Dukungan Keluarga dan Dukungan Petugas Kesehatan pada Ibu yang Memiliki Bayi 6 - 12 Bulan di Posyandu Wilayah Kerja Puskesmas Mamboro

\begin{tabular}{lcc}
\hline \multicolumn{1}{c}{ Variabel } & Frekuensi (n) & Persentase (\%) \\
\hline ASI Eksklusif & & \\
$\quad$ Ya & 26 & 47,3 \\
$\quad$ Tidak & 29 & 52,7 \\
Pengetahuan & & \\
$\quad$ Baik & 29 & 52,7 \\
$\quad$ Kurang Baik & 26 & 47,3 \\
Dukungan Keluarga & & \\
$\quad$ Mendukung & 29 & 52,7 \\
$\quad$ Tidak Mendukung & 26 & 47,3 \\
Dukungan Petugas Kesehatan & & \\
$\quad$ Mendukung & 36 & 65,5 \\
$\quad$ Tidak Mendukung & 19 & 34,5 \\
\hline
\end{tabular}


Berdasarkan tabel 3. yang mendapatkan ASI eksklusif dengan pengetahuan baik sebanyak $62,1 \%$ dan yang tidak mendapatkan ASI eksklusif dengan pengetahuan kurang baik sebanyak $69,2 \%$ hasil uji statistik nilai $p$ value $0,04<0,05$, maka terdapat hubungan yang bermakna antara pengetahuan ibu dengan pemberian ASI eksklusif. Yang mendapatkan ASI eksklusif dan mendapat dukungan keluarga sebanyak $55,2 \%$ dan yang tidak mendapatkan ASI eksklusif dan tidak mendapat dukungan keluarga sebanyak $61,5 \%$ hasil uji statistik nilai $p$ value $0,33>0,05$ maka tidak terdapat hubungan yang bermakna antara dukungan keluarga dengan pemberian ASI eksklusif.

Mendapatkan ASI eksklusif dan mendapat dukungan petugas kesehatan sebanyak 52,8\% dan tidak ASI eksklusif dan tidak mendapatkan dukungan petugas kesehatan sebanyak $63,2 \%$, hasil uji statistik nilai $p$ value $0,40>0,05$ maka tidak terdapat hubungan yang signifikan antara dukungan petugas kesehatan dengan pemberian ASI eksklusif.

Tabel 3. Hubungan Pengetahuan Ibu, Dukungan Keluarga dan Dukungan Petugas Kesehatan dengan Pemberian ASI Eksklusif di Posyandu Wilayah Kerja Puskesmas Mamboro

\begin{tabular}{|c|c|c|c|c|c|c|c|}
\hline \multirow{3}{*}{ Variabel } & \multicolumn{4}{|c|}{ ASI Eksklusif } & \multirow{2}{*}{\multicolumn{2}{|c|}{ Total }} & \multirow{3}{*}{$P$ value } \\
\hline & \multicolumn{2}{|c|}{ Ya } & \multicolumn{2}{|c|}{ Tidak } & & & \\
\hline & $\bar{n}$ & $\%$ & $\mathbf{n}$ & $\%$ & $\mathbf{n}$ & $\%$ & \\
\hline \multicolumn{8}{|l|}{ Pengetahuan } \\
\hline Baik & 18 & 62,1 & 11 & 37,9 & 29 & 100 & \multirow{3}{*}{0,04} \\
\hline Kurang baik & 8 & 30,8 & 18 & 69,2 & 26 & 100 & \\
\hline Jumlah & 26 & 47,3 & 29 & 52,7 & 55 & 100 & \\
\hline \multicolumn{8}{|l|}{ Dukungan Keluarga } \\
\hline Mendukung & 16 & 55,2 & 13 & 44,8 & 29 & 100 & \multirow{3}{*}{0,33} \\
\hline Tidak mendukung & 10 & 38,5 & 16 & 61,5 & 26 & 100 & \\
\hline Jumlah & 26 & 47,3 & 29 & 52,7 & 55 & 100 & \\
\hline \multicolumn{8}{|l|}{ Dukungan Petugas } \\
\hline \multicolumn{8}{|l|}{ Kesehatan } \\
\hline Mendukung & 19 & 52,8 & 17 & 47,2 & 36 & 100 & \multirow{3}{*}{0,40} \\
\hline Tidak mendukung & 7 & 36,8 & 12 & 63,2 & 19 & 100 & \\
\hline Jumlah & 26 & 47,3 & 29 & 52,7 & 55 & 100 & \\
\hline
\end{tabular}

\section{PEMBAHASAN}

\section{Hubungan Pengetahuan Ibu dengan} Pemberian ASI Eksklusif

Peneliti berpendapat bahwa pengetahuan tentang ASI sangat besar pengaruhnya terhadap keberhasilan ASI eksklusif. Seseorang yang paham tentang manfaat ASI tentu akan berusaha memberikan ASI kepada bayinya bagaimanapun caranya sejauh kedua payudara masih dapat memproduksi ASI. Tetapi jika pemahaman ibu masih setengah-setengah yakin dan percaya ASI eksklusif pasti akan gagal. Semakin tinggi pengetahuan seorang ibu tentang ASI eksklusif maka semakin tinggi pula kesadarannya untuk memberikan ASI eksklusif kepada bayinya.

Pengetahuan ibu yang cukup dapat mendasari untuk tindakan pemberian ASI eksklusif kepada bayinya, dimana ibu dengan pengetahuan baik akan lebih memahami pentingnya pemberian dan manfaat ASI eksklusif. Kemudian ibu tersebut akan mengaplikasikan dan merealisasikan secara langsung pemberian ASI eksklusif kepada bayi mereka.

Selain itu dilihat dari karakteristik responden lebih banyak yang berumur 20 - 35 tahun yaitu sebanyak 45 orang, umur tersebut merupakan umur yang ideal untuk melahirkan dan penerimaan ilmu masih mudah. Selain itu kecenderungan untuk memberikan ASI eksklusif masih cukup besar karena umur yang masih produktif. Selain itu, Pendidikan terbanyak yaitu pendidikan tinggi sebanyak $69,1 \%$, menurut Notoatmodjo (2014) pendidikan seseorang berhubungan dengan 
kehidupan sosialnya. Semakin tinggi pendidikan seseorang maka ia akan lebih memperhatikan kesehatannya. Oleh sebab itu, ibu yang pendidikan tinggi akan cenderung memiliki pengetahuan yang baik tentang ASI eksklusif, dan sebaliknya ibu yang memiliki pendidikan rendah cenderung sulit untuk menyerap informasi khususnya pengetahuan tentang ASI eksklusif. Selain itu menurut Haryono dan Setianingsih (2014) pendidikan akan membuat seseorang terdorong untuk ingin tahu, pendidikan mempengaruhi pemberian ASI eksklusif, ibu yang berpendidikan tinggi akan lebih mudah menerima suatu ide dibandingkan dengan ibu yang berpendidikan rendah, sehingga promosi dan informasi mengenai ASI eksklusif dengan mudah dapat diterima dan dilaksanakan.

Hasil penelitian ini sejalan dengan teori yang menyatakan bahwa pengetahuan atau kognitif merupakan domain yang sangat penting dalam terbentuknya tindakan seseorang. Dari pengalaman dan penelitian ternyata perilaku yang didasari oleh pengetahuan akan lebih langgeng dari pada perilaku yang tidak didasari oleh pengetahuan (Notoatmodjo, 2014). Selain itu menurut Haryono dan Setianingsih (2014) salah satu faktor yang mempengaruhi pemberian ASI eksklusif adalah pengetahuan. Pengetahuan hasil dari stimulasi informasi yang diperhatikan dan diingat. Informasi tersebut bisa berasal dari pendidikan formal maupun non formal.

Hal ini juga sejalan dengan penelitian yang dilakukan oleh Susmaneli (2012) yang menyatakan terdapat hubungan antara pengetahuan ibu dengan pemberian ASI eksklusif ( $p$ value 0,001). Penelitian ini dilakukan pada bulan Mei-Juni tahun 2012 dengan sampel 81 responden. Semakin tinggi tingkat pengetahuan seorang ibu, maka semakin tinggi pula kesadarannya untuk memberikan ASI eksklusif kepada bayinya.

Penelitian yang dilakukan oleh Sipahutar dkk (2017) juga sejalan dengan penelitian ini yang menyatakan terdapat pengaruh pengetahuan terhadap pemberian ASI diperoleh nilai $p$ value 0,011 dengan jumlah sampel 97 orang. Uji statistik menunjukan untuk variabel pengetahuan didapat nilai $\mathrm{OR}=3,4$, artinya ibu yang mempunyai pengetahuan kurang memiliki kemungkinan peluang beresiko 3,4 kali tidak memberikan ASI ekslusif. Hasil penelitian ini juga didukung oleh penelitian (Satriani G, Ashriady, \& Mariana, 2019) yang menunjukkan bahwa 52\% responden memiliki pengetahuan tentang ASI Esklusif cukup. Secara statistik pengetahun ibu memiliki hubungan yang bermakna ketika dilakukan analisis bivariabel dengan nilai $\mathrm{p}$ value $=0,006$, sehingga pengetahuan ibu hamil tentang ASI Esklusif dianggap berpengaruh terhadap pemberian ASI Esklusif dibandingkan dengan yang memiliki pengetahuan tentang ASI Eksklusif kurang.

\section{Hubungan Dukungan Keluarga dengan Pemberian ASI Eksklusif}

Hasil penelitian menunjukan dukungan keluarga berdasarkan kepercayaan secara signifikan tidak terdapat hubungan dengan pemberian ASI eksklusif. Dukungan keluarga terutama suami dan orang tua sangat mempengaruhi ibu dalam memberikan ASI ekslusif kepada bayinya. Karena suami adalah pendukung dan penyemangat ibu yang pertama, jika setiap hari didukung dan dimotifasi untuk tetap memberikan ASI tentu pemberian ASI eksklusif akan berhasil. Suami perlu diberikan informasi dan selalu dilibatkan dalam penyuluhan ataupun pemberian informasi terkait ASI ekslusif.

Penelitian ini lebih banyak responden yang mendapat dukungan keluarga dibandingkan dengan responden yang tidak mendapat dukungan keluarga hal ini menunjukan bahwa sebagian besar suami sudah menjalankan perannya dalam mendukung pemberian ASI eksklusif, namun kembali lagi kepada diri seorang ibu yang meyakini dirinya sendiri untuk memberikan ASI, ibu tidak yakin dapat memberikan ASI eksklusif kepada bayinya. Selain itu, karakteristik responden tentang pekerjaan terbanyak adalah tidak bekerja sehingga memudahkan suami atau anggota keluarga dekat melakukan dukungan kepada ibu menyusui agar tercapai ASI ekslusif. Ibu yang tidak bekerja tentunya akan dapat memberikan ASInya kapan saja bayi membutuhkan tanpa jadwal. Dari hasil jawaban responden, keluarga lebih banyak menyarankan pemberian susu formula saat pengeluaran ASI belum lancar.

Menurut teori yang dikemukan oleh Astutik (2017) yang menyatakan suami mempunyai peran memberi dukungan dan ketenangan bagi ibu yang sedang menyusui. Hal ini mencakup seberapa jauh keterampilan 
masing-masing maupun ibu dalam menata dirinya. Begitu pula yang dikemukan oleh Monika (2014) American Academy of Pediactric (AAP) pada 2005 mengeluarkan hasil penelitian mengenai peran penting ayah dalam mensukseskan pemberian ASI. Dukungan ayah dapat meningkatkan kepuasan dan lama waktu ibu dalam menyusui dan meningkatkan adaptasi ayah dan ibu dalam hal mengasuh anak. Selain itu menurut Haryono dan Setianingsih (2014) salah satu faktor yang mempengaruhi pemberian ASI eksklusif adalah faktor pendorong yaitu dukungan keluarga, dukungan dari lingkungan keluarga termasuk suami, orang tua atau saudara lainnya sangat menentukan keberhasilan menyusui. Karena pengaruh keluarga berdampak pada kondisi emosi ibu sehingga secara tidak langsung mempengaruhi produksi ASI. Seorang ibu yang mendapat dukungan dari suami dan anggota keluarga lainnya akan meningkatkan pemberian ASI kepada bayinya. Sebaliknya dukungan yang kurang maka pemberian ASI menurun.

Penilitian ini sejalan dengan penelitian yang dilakukan oleh Sartono dan Utaminingrum (2012) yang menyatakan bahwa analisis logistik regresi linier menunjukan tidak ada hubungan yang bermakna antara dukungan suami dengan praktek pemberian ASI eksklusif. Kondisi tersebut menunjukan bahwa peran dukungan suami kepada ibu dalam praktek pemberian ASI esklusif masih kurang.

Selain itu penelitian ini juga sejalan dengan penelitian yang dilakukan oleh Devita (2013) yang menunjukan tidak ada hubungan yang bermakna antara dukungan keluarga dengan pemberian ASI eksklusif. Ibu yang suaminya mendukung pemberian ASI ekslusif berpeluang memberikan ASI ekslusif 2 kali dari pada ibu yang suaminya kurang mendukung pemberian ASI eksklusif. Oleh karena itu peran suami penting dalam pemberian ASI eksklusif, maka suami harus dijadikan sasaran penyuluhan ASI dan didorong untuk lebih aktif mencari informasi serta aktif belajar mengenai ASI sehingga lebih paham memberikan dukungan kepada ibu.

Berbeda dengan penelitian yang dilakukan oleh Susmaneli (2012) menyatakan terdapat hubungan dukungan keluarga dengan pemberian ASI eksklusif, ibu yang tidak mendapat dukungan keluarga mempunyai peluang 3,2 kali tidak memberikan ASI eksklusif dibandingkan dengan ibu yang mendapat dukungan keluarga.

\section{Hubungan Dukungan Petugas Kesehatan dengan Pemberian ASI Eksklusif}

Variabel dukungan petugas kesehatan berdasarkan kepercayaan secara signifikan tidak terdapat hubungan dengan pemberian ASI ekslusif. Menurut asumsi peneliti sebesar apapun dukungan dan kerja keras dukungan tenaga kesehatan terhadap pemberian ASI ekslusif bagi ibu, penentu utamanya tetaplah ibu itu sendiri.

Apabila tenaga kesehatan sudah mendukung namun dalam diri sendiri ibu tidak mendukung maka hal ini bisa saja menyebabkan gagalnya pemberian ASI eksklusif. Dukungan tenaga kesehatan yang baik tidak akan bermakna jika tidak didukung dari komitmen ibu itu sendiri. Dukungan tenaga kesehatan dapat dilihat dari lebih banyak responden yang dilakukan Inisiasi Menyusu Dini (IMD), tenaga kesehatan tentu akan menganjurkan pemberian ASI ekslusif kepada ibu melahirkan, dan melaksanakan IMD. Menurut Fikawati dan Syafik (2017) IMD merupakan langkah besar menuju keberhasilan ASI eksklusif. Memberikan ASI sejak awal melahirkan memberi kesempatan pada bayi untuk mendapatkan kolostrum pertama yang kaya zat kekebalan tubuh, juga memberi kehangatan langsung ke tubuh bayi, sehingga bisa mengurangi kejadian kematian akibat kedinginan.

Menurut Fikawati dan Syafiq (2016) tenaga kesehatan memegang peranan penting untuk menunjang keberhasilan proses menyusui adapun peranannya adalah memberikan informasi dan edukasi ASI eksklusif kepada ibu maupun anggota keluarga bayi yang bersangkutan sejak pemeriksaan kehamilan sampai dengan periode pemberian ASI ekelusif selesai. Dilarang menerima dan mempromosikan serta memberikan susu formula atau produk bayi yang dapat menghambat program pemberian ASI ekslusif.

Menurut Haryono dan Setianingsih (2014) salah satu faktor yang mempengaruhi pemberian ASI ekslusif adalah faktor pendorong yaitu dukungan petugas kesehatan. Dukungan petugas kesehatan kaitannya dengan nasihat kepada ibu untuk memberikan ASI kepada bayinya menentukan keberlanjutan ibu dalam pemberian ASI. 
Penelitian ini sejalan dengan penelitian yang dilakukan oleh Sohimah dan Lestari (2017) hasil analisis diketahuai bahwa tidak ada pengaruh yang signifikan faktor dukungan tenaga kesehatan terhadap pemberian ASI eksklusif. Petugas kesehatan adalah peletak dasar kecerdasan anak-anak Indonesia karena membimbing ibu untuk memberikan ASI ekslusif. Sikap dan perilaku petugas kesehatan dapat menjadi contoh atau acuan bagi masyarakat tentang hidup sehat. Melihat dari hasil penelitian, diupayakan selain adanya dukungan dari tenaga kesehatan, dan dukungan dari dalam ibu sendiri tentang pentingnya ASI ekslusif dan manfaat juga harus ditingkatkan terutama dalam memberikan informasi tentang ASI ekslusif.

Berbeda dengan penelitian yang dilakukan oleh Windari dkk (2017) bahwa ada pengaruh dukungan tenaga kesehatan terhadap pemberian ASI eksklusif di wilayah kerja Puskesmas Sisir Kelurahan Sisir Kota Batu. Hasil penelitian ini sesuai dengan teori faktorfaktor yang mempengaruhi pemberian ASI ekslusif salah satunya yaitu dukungan dari tenaga kesehatan. Pada penelitian ini juga dianalisa rasio prevalen hasil menunjukan 10,5 hal ini berarti ibu yang mendapat dukungan tenaga kesehatan kurang mempunyai kemungkinan untuk tidak memberikan ASI ekslusif 10,5 kali lebih besar dari pada ibu yang mendapat dukungan kesehatan baik.

\section{KESIMPULAN DAN SARAN}

Hasil penelitian ini menunjukan bahwa terdapat hubungan pengetahuan ibu dengan pemberian ASI eksklusif di Posyandu wilayah kerja Puskesmas Mamboro, tidak terdapat hubungan dukungan keluarga dan dukungan petugas kesehatan dengan pemberian ASI eksklusif di Posyandu wilayah kerja Puskesmas Mamboro.

Bidan dan seluruh petugas kesehatan untuk terus berusaha mengedukasi dan menambah pengetahuan ibu tentang ASI eksklusif, jika memungkinkan lakukan pendampingan selama periode ASI eksklusif, serta senantiasa libatkan suami dalam pemberian informasi terkait tentang ASI.

\section{DAFTAR PUSTAKA}

Astutik, R.Y. (2017). Payudara dan Laktasi. Jakarta Selatan: Salemba Medika.
Devita, R. (2013). Faktor-Faktor Yang Berhubungan dengan Pemberian ASI Ekslusif. Akademi Kebidanan Aisyiyah Palembang, 9(1), 37-46.

Dinas Kesehatan Kota Palu. (2015 \& 2016). Laporan Pemantauan Status Gizi Balita Kota Palu.

Dinas Kesehatan Provinsi Sulawesi Tengah. (2015 \& 2016). Profil Dinas Kesehatan Provinsi Sulawesi Tengah.

Fikawati, S. \& Syafiq, A. dan Karima, K. (2016). Gizi Ibu dan Bayi. Jakarta: PT Rajagrafindo.

Handayani, E. \& Pujiastuti, W. (2016). Asuhan Holistik Masa Nifas dan Menyusui. Yogyakarta: Trans Medika.

Haryono, R. \& Setianingsih, S. (2014). Manfaat ASI Eksklusif untuk Buah Hati Anda. Jogyakarta: Gosyen Publishing.

Kemenkes. (2015 \& 2016). Profil Kesehatan indonesia 2015. http://www.depkes.go.id

Hubungan Tingkat Pengetahuan tentang Air Susu Ibu dan Pekerjaan Ibu dengan Pemberian ASI Eksklusif di Kelurahan Fajar Bulan. Medical Journal of Lampung. 2 (4), 88-99.

Maryunani, A. (2015). Inisiasi Menyusu Dini, ASI Eksklusif dan Manajemen Laktasi. Jakarta: CV Trans Info Media.

Monika, F.B. (2014) Buku Pintar ASI dan Menyusui. Jakarta: Naura Books (PT Misan Publik).

Notoatmojo Soekidjo. (2014). Kesehatan Masyarakat Ilmu \& Seni. Jakarta: Rineka Cipta.

Puskesmas Mamboro. (2015 \& 2016). Laporan Pemantauan Statusn Gizi Balita Puskesmas Mamboro.

Sartono, A \& Utaminingrum, H. (2012). Hubungan Pengetahuan Ibu, Pendidikan Ibu Dan Dukungan Suami Dengan Praktek Pemberian ASI Eksklusif Di Kelurahan Muktiharjo Kidul Kecamatan Telogosari Kota Semarang. Jurnal Gizi Universitas Muhammadiyah Semarang, 1(1), 1-9.

Satriani G, Ashriady, \& Mariana, D. (2019). Faktor-Faktor yang Berhubungan dengan Pemberian ASI Eksklusif di Puskesmas Beru-Beru Kalukku Kabupaten Mamuju Sulawesi Barat. Jurnal Kebidanan, 9 (1), 1-8.http://dx.doi.org /10. 31983/ jkb. v9i1.3880 
Sipuhtar, S, Lubis, NL, \& Siregar, FA. (2017). Hubungan Pengetahuan Ibu, Parietas dan Peran Petugas Kesehatan dengan Pemberian ASI Eksklusif di Wilayah Kerja Puskesmas Siborongborong Tapanuli Utara. Jurnal Akrab Juara, 2(3), 88-95.

Sohimah dan Lestari, YA. (2017). Pengaruh Dukungan Keluarga dan Dukungan Petugas Kesehatan Terhadap Pemberian ASI Eksklusif. Posiding Seminar Nasional dan Presentasi Hasil-Hasil Penelitian Pengabdian Masyarakat, 1(1), 284-291.

Susmaneli, H. (2012). Faktor - Faktor Yang Berhubungan Dengan Pemberian ASI Eksklusif Di Wilayah Kerja Puskesmas Rambah Hilir I Kabupaten Rokan Hulu.
Jurnal Program Studi Kesehatan Masyarakat Stikes Hang Tuah Pekan Baru, 2(2), 67-71.

Windari, EN, Dewi, AK \& Siswanto. (2017). Pengaruh Dukungan Tenaga Kesehatan terhadap Pemberian ASI Ekslusif di Wilayah Kerja Puskesmas Sisir Kota Batu. Journal of issue in midwifery, 1(2), 19-24.

Wowor, M, Joice, ML. \& Pangemanan, D.H.C. (2013). Hubungan Pengetahuan dan Sikap Dengan Pemberian ASI Eksklusif pada Ibu Menyusui di Puskesmas Bahu Kota Manado. EJurnal Keperawatan Program Studi Ilmu Keperawatan Fakultas Kedokteran Universitas Sam Ratulangi Manado,1(1),1-7. 